\title{
CORRECTION OF SEVERE STIFF SCOLIOSIS THROUGH EXTRAPLEURAL INTERBODY RELEASE AND OSTEOTOMY (LIEPO)
}

\author{
CORREÇÃO DE ESCOLIOSE RÍGIDA GRAVE POR LIBERAÇÃO E OSTEOTOMIA \\ INTERSOMÁTICA EXTRAPLEURAL (LIEPO) \\ CORRECCIÓN DE ESCOLIOSIS RÍGIDA GRAVE POR LIBERACIÓN Y OSTEOTOMÍA \\ INTERSOMÁTICA EXTRAPLEURAL (LIEPO)
}

Cleiton Dias Naves ${ }^{1}$, luís Eduardo Carelli Teixeira da Silva ${ }^{1}$, Alderico Girão Campos de Barros ${ }^{1}$, Ayrana Soares Aires'1

Gustavo César de Almeida Peçanha ${ }^{1}$ Gamaliel Gonzáles Atencio ${ }^{1}$

1. Instituto Nacional de Traumatologia e Ortopedia Jamil Haddad (INTO), Rio de Janeiro, RJ, Brazil.

\begin{abstract}
Objective: To report a new technique for extrapleural interbody release with transcorporal osteotomy of the inferior vertebral plateau (LIEPO) and to evaluate the correction potential of this technique and its complications. Method: We included patients with scoliosis with Cobb angle greater than $90^{\circ}$ and flexibility less than 25\% submitted to surgical treatment between 2012 and 2016 by the technique LIEPO at the National Institute of Traumatology and Orthopedics (INTO). Sagittal and coronal alignment, and the translation of the apical vertebra were measured and the degree of correction of the deformity was calculated through the pre and postoperative radiographs, and the complications were described. Results: Patients had an average bleed of $1,525 \mathrm{ml}, 8.8$ hours of surgical time, $123^{\circ}$ of scoliosis in the preoperative period, and a mean correction of $66 \%$. There was no case of permanent neurological damage and no surgical revision. Conclusion: The LIEPO technique proved to be effective and safe in the treatment of severe stiff scoliosis, reaching a correction potential close to the PEISR (Posterior extrapleural intervertebral space release) technique and superior to that of the pVCR (posterior Vertebral Column Resection) with no presence of infection and permanent neurological deficit. New studies are needed to validate this promising technique.
\end{abstract}

Keywords: Scoliosis/surgery; Spine/surgery; Osteotomy; Treatment outcome.

\section{RESUMO}

Objetivo: Relatar uma nova técnica de liberação intersomática extrapleural associada a osteotomia transcorporal do platô vertebral inferior (LIEPO) e avaliar o potencial de correção dessa técnica e suas complicações. Método: Foram incluídos pacientes com escoliose com ângulo de Cobb maior que $90^{\circ}$ e flexibilidade menor que 25\%, submetidos ao tratamento cirúrgico entre 2012 e 2016 pela técnica LIEPO, no Instituto Nacional de Traumatologia e Ortopedia (INTO). Foram aferidos alinhamento sagital, coronal e a translação da vértebra apical e calculou-se o grau de correção da deformidade através das radiografias pré e pós-operatórias, sendo descritas as complicações encontradas. Resultado: Os pacientes tiveram média de sangramento de $1.525 \mathrm{ml}$, 8,8 horas de tempo cirúrgico, $123^{\circ}$ de escoliose no pré-operatório e média de correção de 66\%. Não houve caso de lesão neurológica permanente e nenhuma revisão cirúrgica. Conclusão: A técnica LIEPO mostrou-se eficaz e segura no tratamento de escoliose rígida grave, atingindo um potencial de correção próximo ao da técnica PEISR ("Posterior Extrapleural Intervertebral Space Release") e superior ao da RCVp (Ressecção de Coluna Vertebral via posterior) sem presença de infecção e déficit neurológico permanente. Novos estudos são necessários para a validação dessa técnica promissora.

Descritores: Escoliose/cirurgia; Coluna vertebral/cirurgia; Osteotomia; Resultado do tratamento.

\section{RESUMEN}

Objetivo: Reportar una nueva técnica de liberación intersomática extrapleural asociada a la osteotomía transcorporal de la meseta vertebral inferior (LIEPO) y evaluar el potencial de corrección de esta técnica y sus complicaciones. Método: Se incluyeron pacientes con escoliosis con ángulo de Cobb superior a $90^{\circ}$ y flexibilidad inferior al 25\%, sometidos al tratamiento quirúrgico entre 2012 y 2016 por la técnica LIEPO, en el Instituto Nacional de Traumatología y Ortopedia (INTO). Se evaluaron la alineación sagital y coronal y la translación de la vértebra apical y se calculó el grado de corrección de la deformidad a través de las radiografías pre y postoperatorias, siendo descritas las complicaciones encontradas. Resultado: Los pacientes tuvieron media de sangrado de 1.525 ml, 8,8 horas de tiempo quirúrgico, $123^{\circ}$ de escoliosis en el preoperatorio y promedio de corrección del 66\%. No hubo casos de lesión neurológica permanente y ninguna revisión quirúrgica. Conclusión: La técnica LIEPO se mostró eficaz y segura en el tratamiento de la escoliosis rígida grave, alcanzando un potencial de corrección cercano al de la técnica PEISR ("Posterior extrapleural intervertebral space release") y superior al de la RCVp (Resección de columna vertebral vía posterior); sin presencia de infección y déficit neurológico permanente. Se necesitan nuevos estudios para validar esta técnica prometedora.

Descriptores: Escoliosis/cirugía; Columna vertebral/cirugía; Osteotomía; Resultado del tratamiento. 


\section{INTRODUCTION}

The treatment of severe stiff scoliosis is a challenge for spine surgeons. ${ }^{1}$ The literature brings us two main classic correction techniques used in the treatment of these deformities. The traditional combined approach 2,3 (anterior + posterior), in which discectomy, anterior longitudinal ligament release, posterior longitudinal ligament release, resection of intervertebral discs, resection of the rib head, and osteotomy of the vertebral body are performed via anterior approach, and subsequently, on the same day or in a second surgery, correction is performed via posterior approach with resection of the facet joints, laminas, and yellow ligament, and arthrodesis with instrumentation. If the two-step procedure is chosen, the patient may be kept in halo-gravitational traction during the period between the two procedures. ${ }^{4}$ This procedure requires longer surgical time and has higher morbidity as compared to other techniques, especially when applied to patients with compromised respiratory function, starting in the preoperative period, due to the nature of the restrictive lung disease secondary to the spinal deformity.

The second technique disseminated in the literature in recent years is the posterior vertebral column resection (pVCR), published by Suk et al. ${ }^{5}$ This technique has lower morbidity because of its use of a single access, through which Schwab grade $\mathrm{V}$ or $\mathrm{VI}^{6}$ vertebral body osteotomies at the apex of the curve can be performed, which permits good correction of the deformity through this region, but generates at this point an area of high instability that increases the risk of accidental spinal cord lesion during the execution of the correction maneuvers. Scoliosis is corrected mostly through this region, with two rigid blocks remaining proximal and distal to the apical region.

In order to improve the correction of rigid scolioses, attempting to minimize the problems identified in the Suk technique, in 2012, the group of Li et al., ${ }^{7}$ presented their posterior extrapleural interbody intervertebral space release (PEISR) technique, using an exclusively posterior approach aimed at flexibilizing the spinal deformity in a harmonic manner in the regions both proximal and distal to the apex of the curve. Associated with this approach, the group performed a posterior wedge osteotomy in the apical region of the deformity, introduced by Shimode et al., ${ }^{8}$ and widely reported in the literature.

We also used the posterior extrapleural interbody intervertebral space release technique in our case series, performing multiple osteotomies of the inferior plateau of the vertebrae adjacent to the apex of the deformity, two to three levels proximal and distal to the apex vertebra, removing the intervertebral discs at the same time, instead of performing the posterior wedge osteotomy of the apical vertebra according to the Li et al. ${ }^{7}$ technique.

The objective of this study was to describe a modification to the posterior extrapleural interbody intervertebral space release technique for correction of spinal deformities associated with transcorporal osteotomies of the inferior plateau (LIEPO - Liberação Interssomática ExtraPleural com Osteotomia); as well as to evaluate the degree of correction and the complications that occurred in both the early and late postoperative periods in patients submitted to this new LIEPO technique.

\section{METHODS}

The study was a retrospective analysis of a case series of patients who underwent surgery to correct severe rigid surgery during the period from 2012 and 2016 at the Instituto Nacional de Traumatologia e Ortopedia Jamil Haddad (INTO). The information was obtained from the work database approved by the CAAE Ethics Commitee: 41659215.0.0000.5273. The authors signed the Statement of Investigator, in which they ethically committed to the confidentiality and professional use of the data obtained from the medical records. Six patients who underwent the modified posterior extrapleural interbody intervertebral space release technique (PEISR), ${ }^{7}$ associated with osteotomies of the inferior vertebral plateau of the vertebrae adjacent to the apex of the deformity, as shown in Figure 1, resection of the intervertebral discs, the anterior longitudinal ligament, the posterior longitudinal ligament, and the rib head section of the concave side

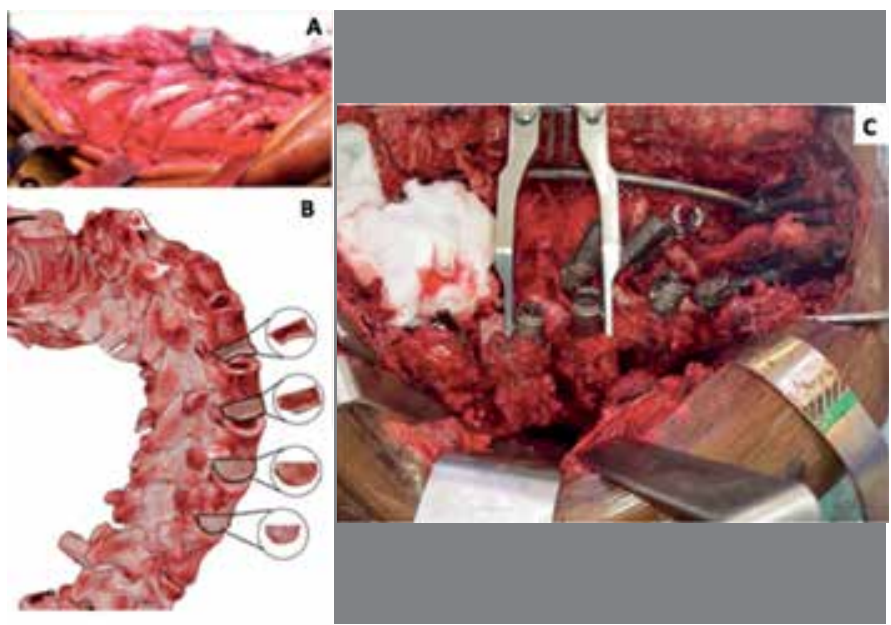

Figure 1. Osteotomies of the inferior plateau.

of the curve (LIEPO). The inclusion criteria were patients with coronal deformity greater than 90 Cobb degrees and with less than 25\% flexibility confirmed by lateral inclination radiographic tests.

Six patients, two men and four women, were included in this study. The average age was 18 years ( $13-23$ years). The diagnosis was idiopathic scoliosis in five cases and syndromic scoliosis in one case. In all cases, the apex of the curve was located in the thoracic spine. All the patients participated in follow-up for a minimum of 12 months, with clinical evaluations and imaging exams.

We evaluated the clinical history, demographic data, surgical time, estimated blood loss, functional improvement, and complications by analyzing the medical records. Calibration of the magnitude of the curves and the study of sagittal balance were conducted using anterior-posterior and lateral panoramic radiographs obtained both pre- and postoperatively. Atypical vertebral translation (AVT) was measured by the interval between a plumb line passing through the center of $\mathrm{C} 7$ and the center of the apical vertebra or disc. Coronal deformity was measured using the Cobb method. Thoracic kyphosis was measured using the Cobb method between the superior terminal plate of T5 and the inferior terminal plate of T12. Sagittal alignment was measured by the distance between the plumb line from $\mathrm{C} 7$ and the posterior-superior portion of S1. All the measurements were taken by a researcher not directly involved in the surgical procedure, using the Surgimap ${ }^{\circledR}$ computer program.

\section{RESULTS}

Six patients were included in the study. The etiology of the scoliosis was idiopathic in five cases and syndromic in one case, in which the patient had Treacher Collins syndrome.

The patient demographic data are presented in Table 1. The average number of discs excised per patient was $4.3(3-5)$, the average number of osteotomies of the inferior vertebral plateau for extrapleural access was $2.7(2-3)$, the average number of vertebrae involved in the area of the arthrodesis was $13.2(11-15)$, the average surgical time was $8.8 \mathrm{~h}(8-10 \mathrm{~h})$, the average estimated bleeding was $1525 \mathrm{ml}(900-2300 \mathrm{ml})$, with an average variation in the hemoglobin count from the perioperative period to the first postoperative day of 4.3 points $(2.6-6.7)$, which corresponds to an estimated $34 \%$ loss of red blood cell volume in the first $24 \mathrm{~h}$ after the surgical procedure. The average length of stay in an intensive care unit was 9.3 days $(5-18)$ and the average outpatient clinic follow-up was 30 months, ranging from 12 to 58 months.

The radiographic parameters are presented in Table 2 and illustrated in Figures 2 to 6 . The average preoperative angular value of the principal curve was $123.6^{\circ}\left(97^{\circ}-157^{\circ}\right)$, with an average flexibility of $11 \%(5-21 \%)$, which was corrected to $43^{\circ}\left(18^{\circ}-66^{\circ}\right)$, corresponding to a correction of $65.22 \%$. The average value of translation of the apical vertebra was $10.58 \mathrm{~cm}(3.76-17.6 \mathrm{~cm})$ in the preoperative 
Table 1. Clinical results of patients submitted to correction of scoliosis using the LIEPO technique.

\begin{tabular}{|c|c|c|c|c|c|c|c|c|c|c|}
\hline Patient No. & Sex & Age & Diag. & OTT & DR & No. of A.V. & ST (h) & $\mathrm{VHb}$ & F-U (months) & ICU (days) \\
\hline 1 & $\mathrm{~F}$ & 15 & AIS & 3 & 5 & 15 & 9 & 5.7 & 58 & 13 \\
\hline 3 & $\mathrm{~F}$ & 17 & AIS & 2 & 3 & 14 & 8 & 2.9 & 18 & 7 \\
\hline 5 & $M$ & 23 & AIS & 3 & 5 & 11 & 9 & 6.7 & 25 & 6 \\
\hline 6 & $\mathrm{~F}$ & 13 & SS & 3 & 5 & 11 & 9 & 4.7 & 50 & 5 \\
\hline
\end{tabular}

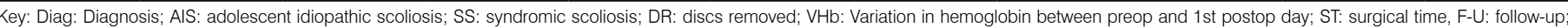
A.V.: arthrodesed vertebrae; OTT: osteotomy levels.

Table 2. Radiographic results of patients submitted to the correction of scoliosis using the LIEPO technique.

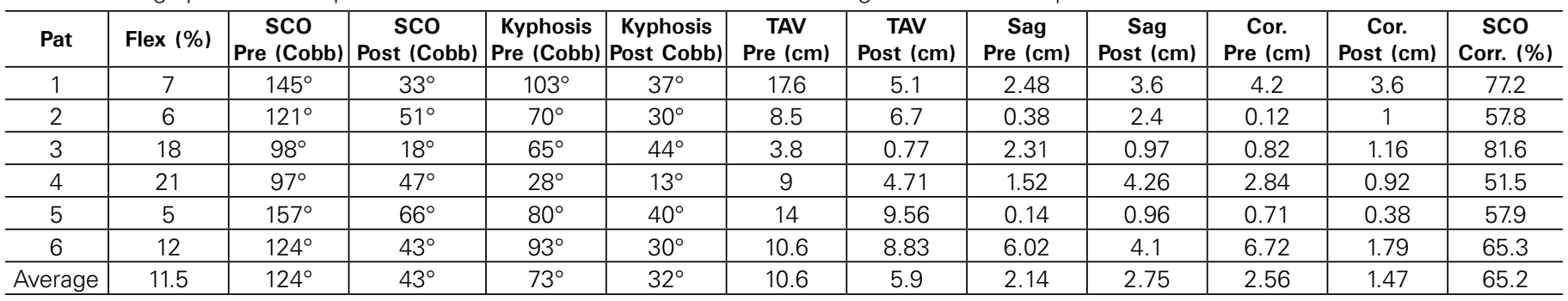

Key: Pat: Patient; Flex: Flexibility; SCO: Scoliosis; TAV: translation of the apical vertebra; Sag: Sagittal alignment; Cor: Coronal alignment.
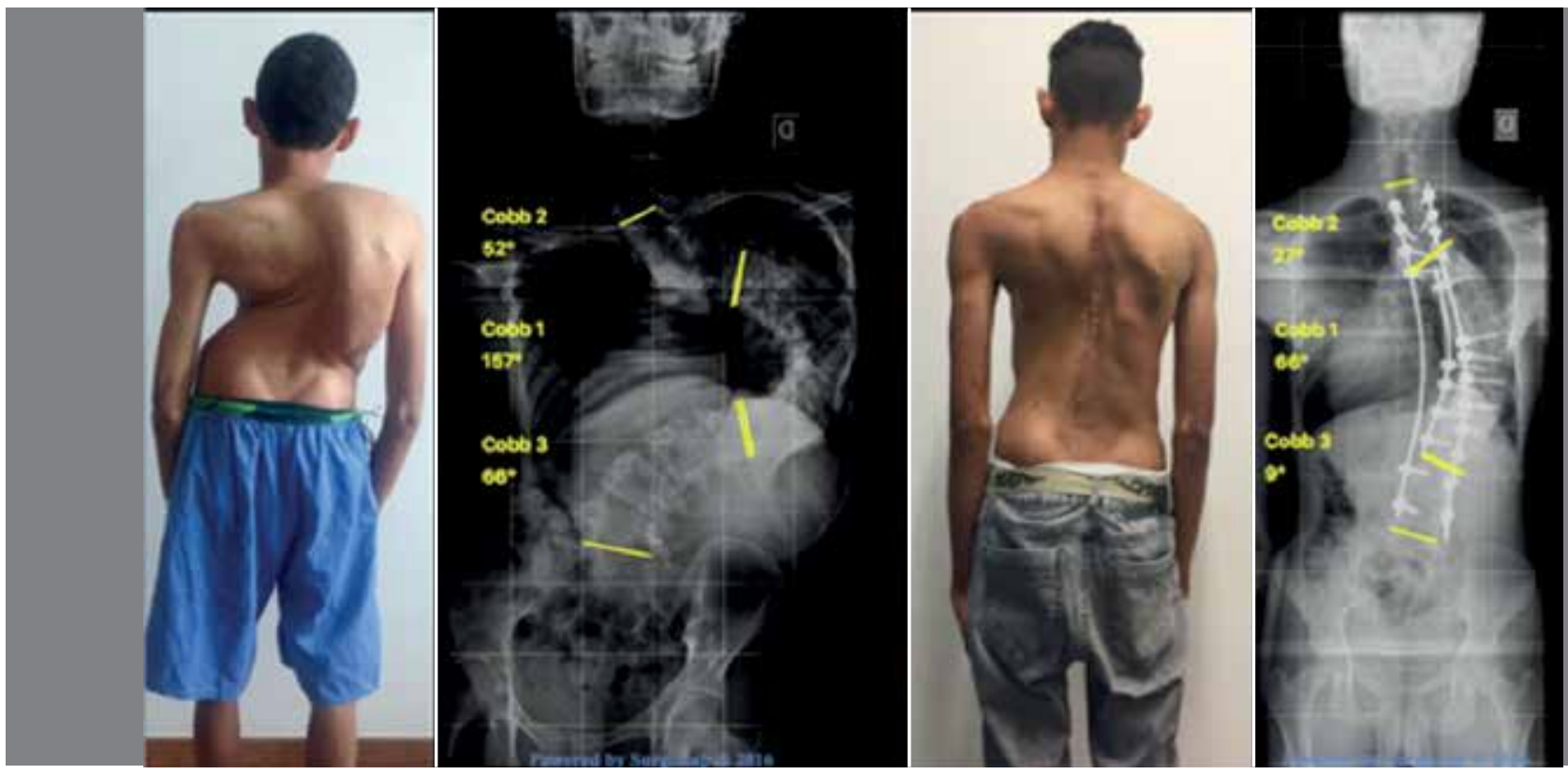

Figure 2. Pre- and postoperative clinical and radiographic images in the coronal plane.

period, corrected to $5.94 \mathrm{~cm}(0.77-9.56)$ in the postoperative period, corresponding to $43.9 \%$ correction. The average preoperative thoracic kyphosis was $73.2^{\circ}\left(28^{\circ}-103^{\circ}\right)$ corrected to $32.3^{\circ}\left(13^{\circ}-44^{\circ}\right)$, for a correction of $55.81 \%$. Preoperative sagittal alignment changed from $1.68 \mathrm{~cm}(0.14-6.02)$ to $-5.49 \mathrm{~cm}(-42.1-41.02)$. Preoperative coronal alignment went from $2.57 \mathrm{~cm}(0.12-6.72)$ to $1.47 \mathrm{~cm}(0.38-3.60)$, for a $42.6 \%$ correction.

As complications, we observed one patient who developed neurological deficit in the peri- and immediate postoperative periods, evolving with a neurogenic bladder and presenting total improvement of the deficit at the final outpatient consultation. One patient evolved with pneumonia and another with a postoperative urinary tract infection. Both were treated with intravenous antibiotic therapy and were discharged after clinical improvement. A chest drain with water seal was routinely placed in all patients immediately following the surgical procedure and remaining for less than 1 week in all cases, aimed at preventing the more serious complication of a possible hemopneumothorax. None of the patients had chylothorax. None of the patients required surgical revision and there were no cases of muscle necrosis, permanent neurological lesion, or infection of the surgical site.

Five patients were operated on in two stages. In the first surgery, we performed pedicle instrumentation, Ponte osteotomies, release of the yellow ligament, and placement of the cranial halo, which remained for two weeks in the patients under halo-gravitational traction at a weight corresponding to $20 \%$ to $30 \%$ of their body weight.

In the second surgery, two weeks after the first procedure, we performed extrapleural interbody release associated with transcorporal osteotomy of the inferior plateau of the periapical vertebrae (LIEPO), scoliosis correction, and system locking maneuvers, and the removal of the cranial halo, thus obtaining correction of the spinal deformity. 


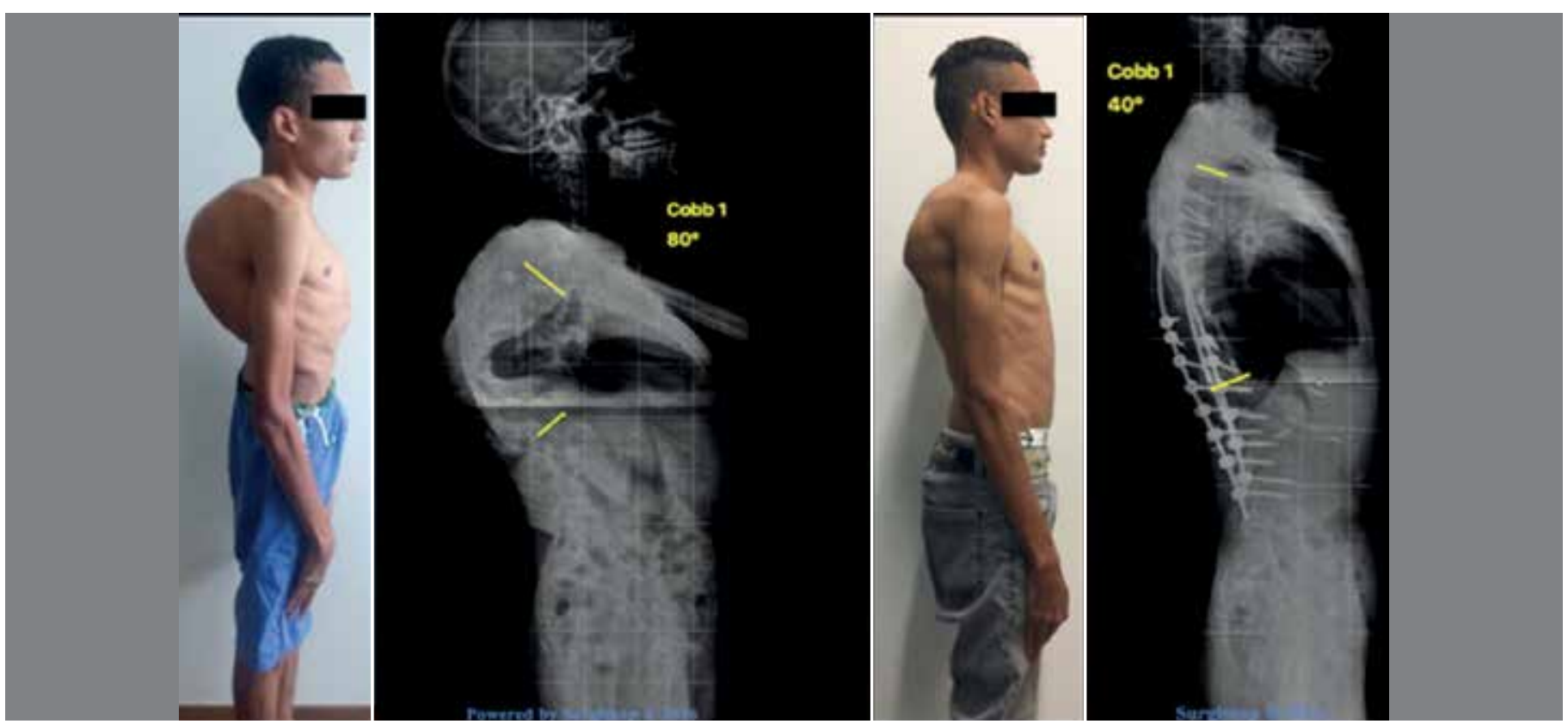

Figure 3. Pre- and postoperative clinical and radiographic images in the sagittal plane.
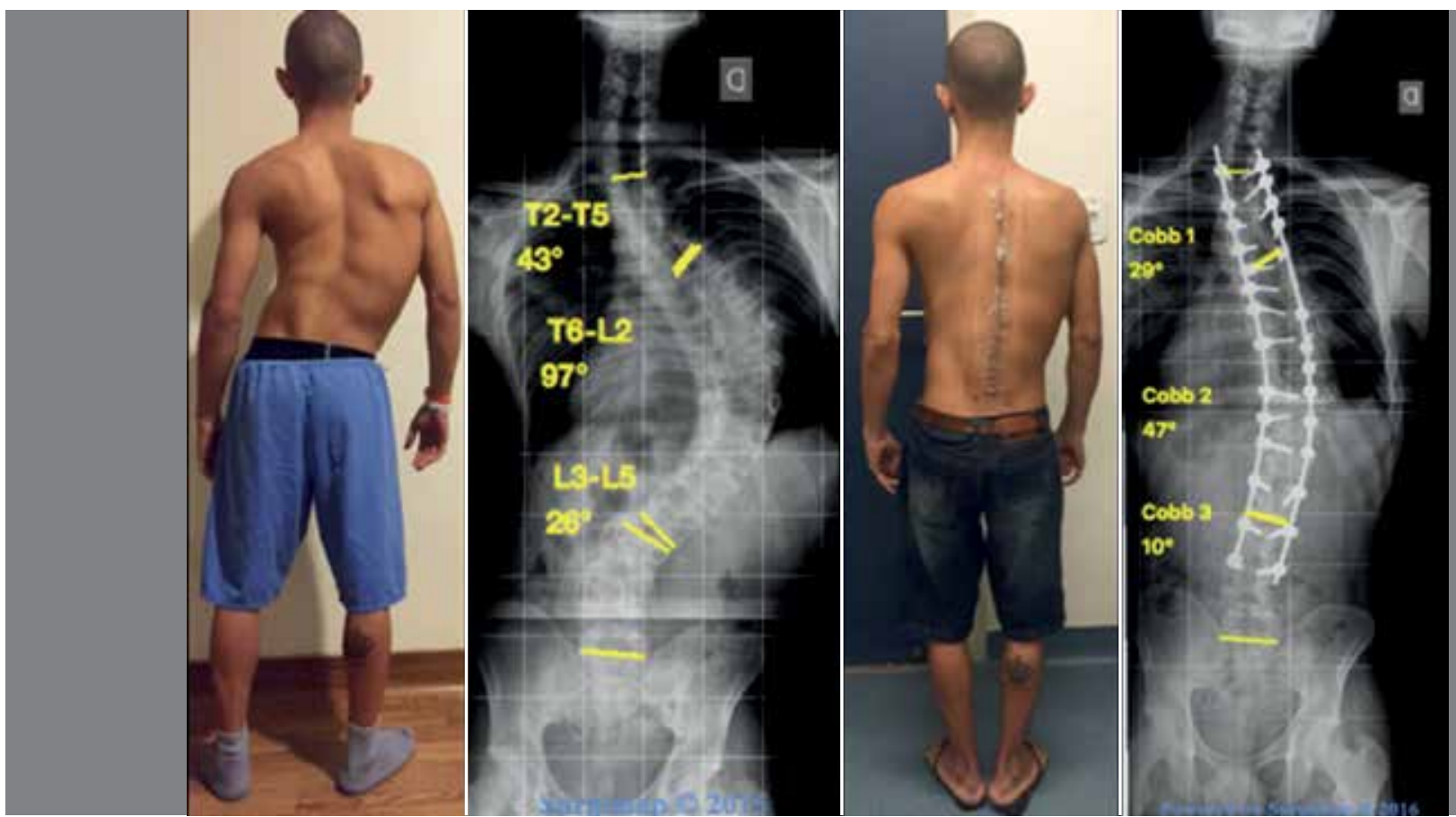

Figure 4. Pre- and postoperative clinical and radiographic images in the coronal plane.

\section{DISCUSSION}

The treatment of severe rigid spinal deformities is still challenging today, despite technical surgical improvement, the availability of modern implants, and the use of advanced technological resources like intraoperative navigation and neuromonitoring. . $^{8-10}$ The literature shows that historically patients with curves greater than $70^{\circ}$, or those who remain at magnitudes greater than $50^{\circ}$ in lateral inclination tests, should be operated by combined approach in order to perform anterior ligament release associated with correction via posterior approach. Thus, Li et al. ${ }^{2}$ achieved a correction rate of $48.6 \%$ in their series of 31 cases with an average preoperative Cobb of $98^{\circ}$.

Scoliosis with a high angular value can be treated by anterior approach alone according to Shen et al., ${ }^{11}$ who described their study in which they performed anterior release associated with instrumentation and fusion in 12 patients with an average Cobb of $98.5^{\circ}$, obtaining $59.5 \%$ correction.

Anterior release via thoracoscopy prior to posterior arthrodesis has been described as being less invasive and optimizing clinical results, but the technical difficulty of this procedure in patients with severe deformity of the thoracic cage is a limiting factor. Moreover, Picetti et al. ${ }^{12}$ demonstrated that this procedure should be reserved for patients with good pulmonary function.

Bradford described circumferential vertebral column resection (cVCR), via double approach, published together with Tribus, ${ }^{13}$ a series of 24 patients with severe rigid scoliosis, with an average deformity of $103^{\circ} \mathrm{Cobb}$ in the coronal plane, obtaining $52 \%$ correction with their technique, requiring more than $12 \mathrm{~h}$ of surgical time, and with a loss of volume greater than observed in other techniques. 


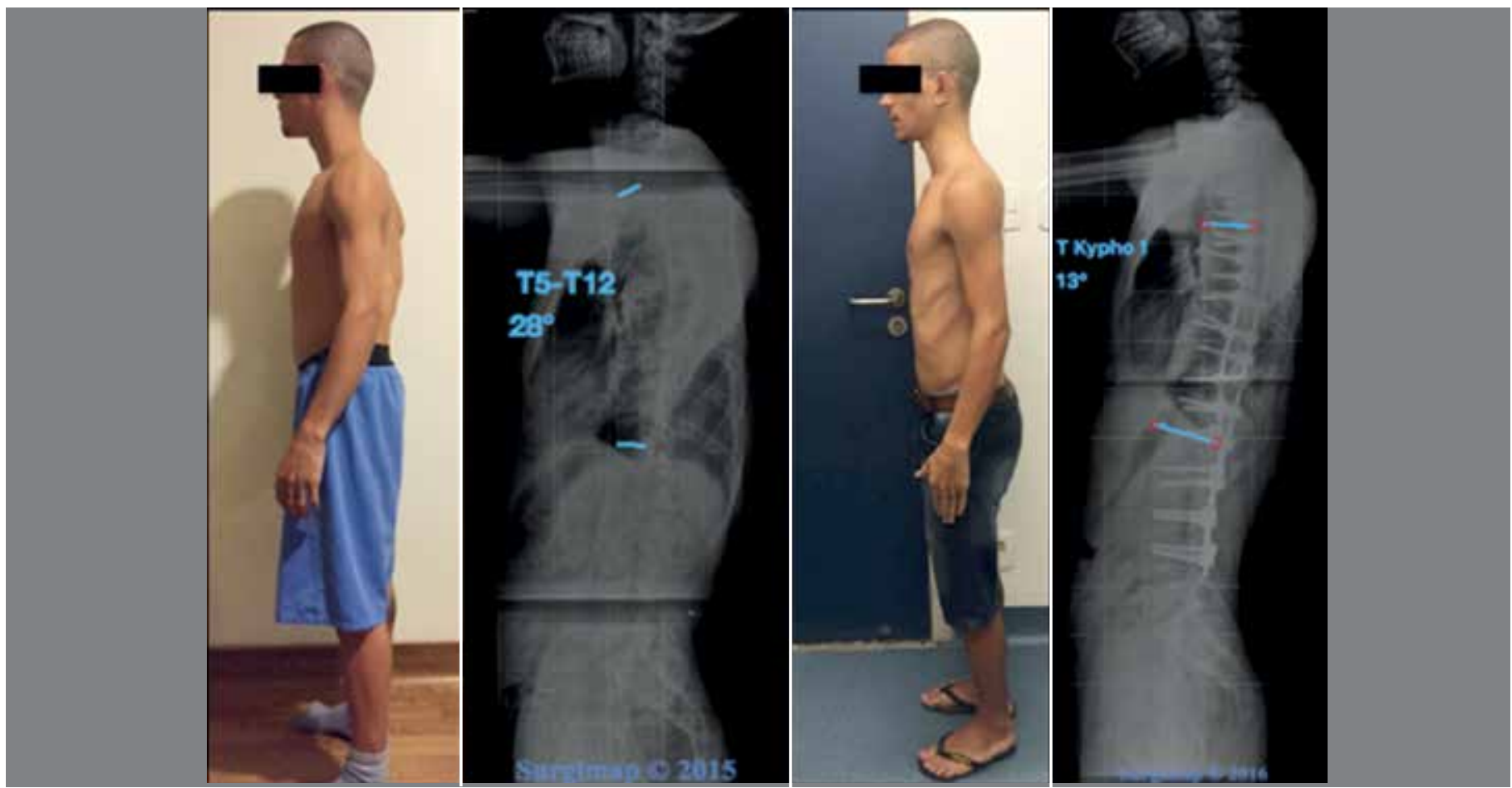

Figure 5. Pre- and postoperative clinical and radiographic images in the sagittal plane.
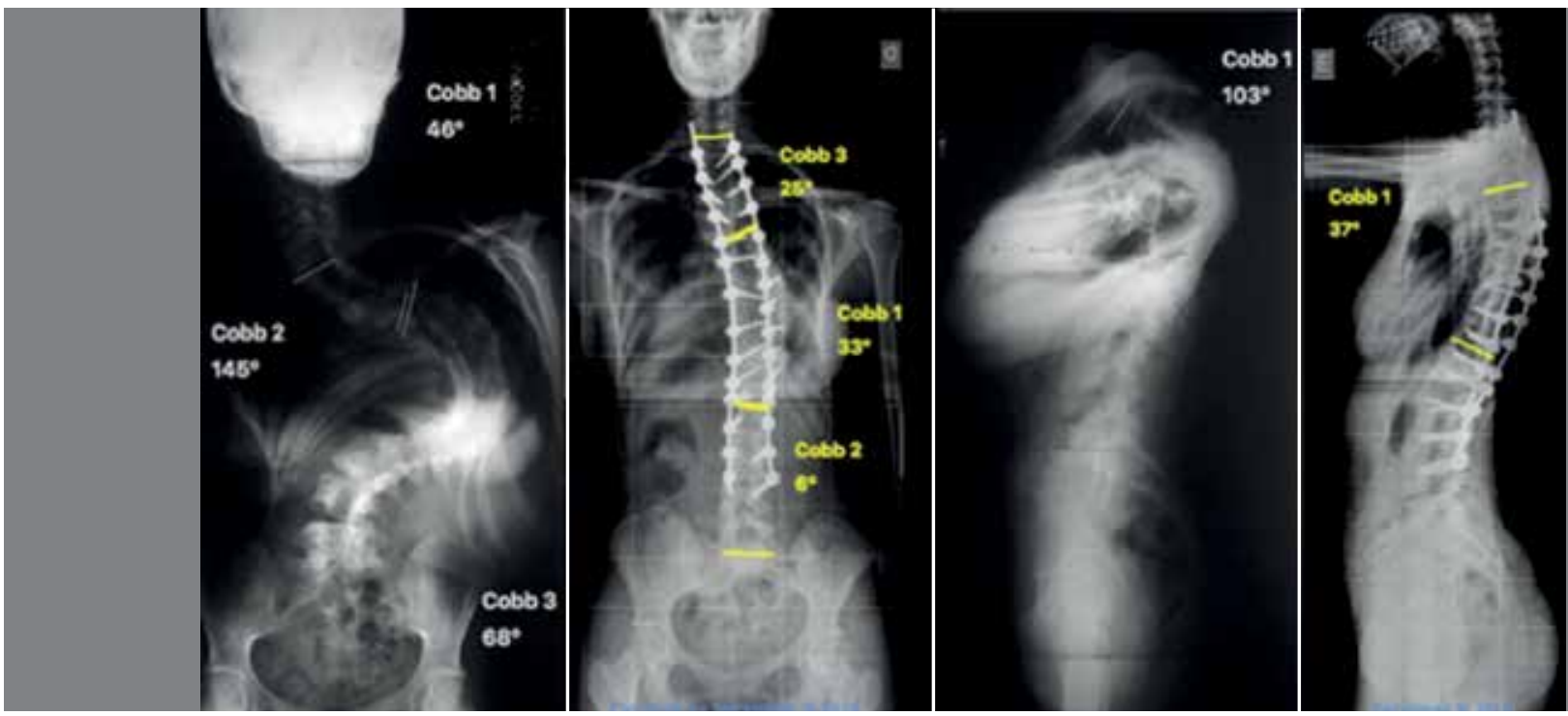

Figure 6. Per- and postoperative radiographs in the sagittal and coronal planes.

Suk et al. ${ }^{5}$ presented an exclusively posterior approach in which anterior release associated with posterior fixation is performed. In this series of 16 cases, they performed pVCR in patients with an average preoperative Cobb of $109^{\circ}$ in the coronal plane, obtaining 59\% correction. There were four serious complications and one patient evolved with permanent paralysis.

In 2002, Shimode et al. ${ }^{8}$ described a wedge osteotomy technique at the apex of the deformity in patients with kyphoscoliosis, in which they obtained $54.9 \%$ correction in patients with an average Cobb of $85.3^{\circ}$ in the coronal plane. Lemko achieved $51 \%$ correction $^{1}$ with pVCR in a series of 35 patients with an average preoperative Cobb of $115^{\circ}$.

The pVCR technique consists of a vertebral resection osteotomy at the apex of the deformity, allowing significant correction of the curve through this point, leaving two rigid blocks proximal and distal to the excised segment, generating instability in the apical region, which causes the possibility of spinal cord injury occurring at this point, mostly due to the accumulation of tension in the rigid segments. ${ }^{14}$

Li et al. ${ }^{7}$ described the technique of posterior extrapleural interbody intervertebral space release (PEISR) associated with wedge osteotomy of the apex of the deformity, aimed at reducing the limitations encountered in the pVCR and at homogenizing gradual correction in the proximal and distal blocks through release at several interbody levels.

We obtained correction of $65 \%$, a value close to the $71 \%$ of the Chao Li group and greater than the correction percentage achieved by other techniques such as Suk et al. ${ }^{5}$ using the pVCR technique (59\%), (Table 3) with low blood loss. None of our patients suffered permanent neurological damage or required a new surgical intervention.

Our average scoliosis value at diagnosis was $123^{\circ}\left(97^{\circ}-157^{\circ}\right)$ Cobb, with $66 \%$ of the patients with curves greater than $120^{\circ} \mathrm{Cobb}$. This value stands out because, in all the other studies, less than $40 \%$ of the patients had preoperative curves greater than $120^{\circ}$. 
Table 3. Comparison of percent correction obtained with the respective surgical techniques.

\begin{tabular}{|c|c|c|c|c|}
\hline Author & Technique & Cases & Average & $\begin{array}{c}\text { Correction } \\
(\%)\end{array}$ \\
\hline $\begin{array}{l}\text { Ming Li. J Paediatr } \\
\text { Child Health } 2009\end{array}$ & $A R+P S F$ & 31 & $98^{\circ}$ & $48.6 \%$ \\
\hline Bradford DS. Spine 1997 & cVCR & 24 & $103^{\circ}$ & $52 \%$ \\
\hline Shimode M. Spine 2002 & WO & 7 & $85.3^{\circ}$ & $54.9 \%$ \\
\hline Se-II Suk. Spine 2005 & pVCR & 16 & $109^{\circ}$ & $59 \%$ \\
\hline Jianxiong She. Spine 2006 & A - Only & 12 & $98.5^{\circ}$ & $59.5 \%$ \\
\hline Teixeira da Silva, LEC 2017 & LIEPO & 6 & $123^{\circ}$ & $65 \%$ \\
\hline Chao Li. Spine 2012 & PEISR & 18 & $108^{\circ}$ & $72 \%$ \\
\hline
\end{tabular}

\section{CONCLUSIONS}

The extrapleural interbody release technique associated with transcorporal osteotomy of the inferior plateau of the vertebrae (LIEPO) proved to be safe and effective when used in the correction of severe rigid spinal deformity, yielding a satisfactory percentage of correction.

New studies with larger numbers of patients are necessary for the validation of this promising technique, which comes complemented by an arsenal of surgical approaches used in the correction of spinal deformities.

All authors declare no potential conflict of interest related to this article.

CONTRIBUTION OF THE AUTHORS: Each author made significant individual contributions to this manuscript. CDN and LECTS were the main contributors to the preparation of the manuscript. ASA, GGA, CDN and GCAP participated in the surgical procedures as assistants, followed-up clinically with the patients, and collected clinical data. LECTS and AGC were the lead surgeons for all cases and obtained pre-, peri-, and postoperative clinical and radiological data. The LIEPO technique was designed and developed by LECTS. CDN, GGA and GCAP conducted the statistical analysis and built the tables. CDN and LECTS produced the images and photographs. CDN, ASA, LECTS, AGC, GCAP and GGA worked on the bibliographical research, manuscript review, and they contributed to the discussion of the results of the manuscript review and to the intellectual concept of the study.

\section{REFERENCES}

1. Lenke LG, O'Leary PT, Bridwell KH, Sides BA, Koester LA, Blanke KM. Posterior vertebral column resection for severe pediatric deformity: minimum two-year follow-up of thirty-five consecutive patients. Spine (Phila Pa 1976). 2009:34(20):2213-21.

2. Li M, Ni J, Li Y, Fang X, Gu S, Zhang Z, et al. Single-staged anterior and posterior spinal fusion: a safe and effective alternative for severe and rigid adolescent idiopathic scoliosis in China. J Paediatr Child Health. 2009;45(5):246-53.

3. Boachie-Adjei O, Bradford DS. Vertebral column resection and arthrodesis for complex spinal deformities. J Spinal Disord. 1991;4(2):193-202.

4. Sponseller PD, Takenaga RK, Newton P, Boachie O. Flynn J, Letko L, et al. The use of traction in the treatment of severe spinal deformity. Spine (Phila Pa 1976). 2008;33(21):2305-9

5. Suk SI, Chung ER, Kim JH, Kim SS, Lee JS, Choi WK. Posterior vertebral column resection for severe rigid scoliosis. Spine (Phila Pa 1976). 2005:30(14):1682-7.

6. Schwab F, Blondel B, Chay E, Demakakos J, Lenke L, Tropiano P, et al. The comprehensive anatomical spinal osteotomy classification. Neurosurgery. 2014;74(1):112-20

7. Li C, Fu Q, Zhou Y, Yu H, Zhao G. Posterior extrapleural intervertebral space release combined with wedge osteotomy for the treatment of severe rigid scoliosis. Spine (Phila $\mathrm{Pa}$ 1976). 2012;37(11):E647-54
8. Shimode M, Kojima T, Sowa K. Spinal wedge osteotomy by a single posterior approach for correction of severe and rigid kyphosis or kyphoscoliosis. Spine (Phila Pa 1976) 2002:27(20):2260-7.

9. Agarwal N, Hamilton DK, Ozpinar A, Choi P, Hart R, Yaylali I. Intraoperative Neurophysiologic Monitoring for Adult Patients Undergoing Posterior Spinal Fusion. World Neurosurg. 2017:99:267-74

10. Al-Habib AF, Al-Akkad S. Segmental surface referencing during intraoperative three-dimensional image-guided spine navigation: an early validation with comparison to automated referencing. Global Spine J. 2016:6(8):765-770.

11. Shen J, Qiu G, Wang Y, Zhang Z, Zhao Y. Comparison of 1-stage versus 2-stage anterior and posterior spinal fusion for severe and rigid idiopathic scoliosis-a randomized prospective study. Spine (Phila Pa 1976). 2006;31(22):2525-8.

12. Picetti GD 3rd, Pang D, Bueff HU. Thoracoscopic techniques for the treatment of scoliosis: early results in procedure development. Neurosurgery. 2002;51(4):978-84.

13. Bradford DS, Tribus CB. Vertebral column resection for the treatment of rigid coronal decompensation. Spine (Phila Pa 1976). 1997;22(14):1590-9.

14. Teixeira da Silva LE, de Barros AG, de Azevedo GB. Management of severe and rigid idiopathic scoliosis. Eur J Orthop Surg Traumatol. 2015;25 Suppl 1:S7-12. 